$\underline{3}$

\title{
The County Historical Society: Financial and Reporting Issues
}

Jane E. Baird, (E-mail: jane.baird@mnsu.edu), Minnesota State University

Mary S. Rolfes, (E-mail: mary.rolfes@mnsu.edu), Minnesota State University

\section{INTRODUCTION}

$\mathscr{J}$

essie Star, a recent accounting graduate from State University, has just volunteered (at the urging of her boss) to be the treasurer for the local Historical Society. The County Historical Society is a not-for-profit organization that operates a museum displaying historical artifacts and an archive library housing historical documents and photographs. The Society also operates a gift shop in its museum and manages a historical home owned by the county government. The museum, library, storage areas, and offices are located in a building rented from a local corporation. The historical home is located just a few blocks away. The Society has three employees on its payroll: Robert James, the full-time Executive Director, Erika Lawson, the part-time Museum Assistant, and an Archive Librarian, John Nelson. A volunteer Board of Trustees, consisting of twelve members from the community, directs the Society. As Treasurer, Jessie is an officer and member of the Board of Trustees. She has the primary responsibility for maintaining the Society's books, making investment/financing recommendations to the Board, and assisting with the annual external audit of the financial statements.

Jesse has been struggling to get up to speed with the Society's accounting so that she'll be ready for her first Board meeting. She is not very familiar with Fund Accounting and has never been involved with this type of not-forprofit organization. Jessie set up a meeting with the former treasurer, Al Gone, to help her get up to speed with the issues.

\section{JESSIE MEETS WITH AL GONE}

Jessie: Hi Al, I appreciate you meeting with me. Could we start with a general discussion of the fund accounting at the Society? You know, what kinds of funds the company has.

Al: Sure. Well, for starters, resources for accounting and reporting purposes are classified into funds established according to their nature and purpose. Separate accounts are maintained in the accounting records for each fund. The Society maintains five funds in the accounting records.

The Operating Fund includes all the items related to the normal operations of the Museum. The assets and revenues in this fund are not designated for any specific use, so they can be used for any purposes related to the Society. All cash receipts and expenditures for this fund go through a North Bank checking account.

The Fixed Asset Fund includes all the leasehold improvements, furniture, fixtures and office equipment owned by the Society.

The Endowment Fund represents restricted donations that have to be maintained so that only the earnings can be spent by the Society. These funds are in a savings account and Certificates of Deposit at City Bank.

The Restoration Fund represents restricted donations that can only be spent for restoring and furnishing the house operated by the society. That money, right now, is in Certificates of Deposit and in a checking account at City Bank. 
The last fund is the Marketing Fund. A contributor donated this money for advertising of the Society and its activities. So, that money is restricted and can't be used for anything else. The cash is in a savings account at National Bank.

Jessie: Great. That helps a lot. Could we go over the individual accounts too? What types of assets, liabilities, revenues and expenses does the Society have?

Al: O.K. Well, let's start with the assets. The Society reports Cash, Accounts Receivable, Prepaid Insurance, Inventory, and Building \& Equipment assets on its balance sheet. Cash includes all cash on-hand in the cash register in the gift shop, all the cash in checking and savings accounts, and all of the money invested in Certificates of Deposit for all the funds. Each bank account and CD account has its own account set up in the accounting records. Accounts Receivable is usually a small amount, because it is just money owed by patrons for research done by John. A lot of times people will call on the phone and ask John to research something and then he bills them later. The Prepaid Insurance is what is paid in advance on the insurance policies.

The inventory includes all the items for sale in the gift shop. The Society has always used the first-in, first out (FIFO) method for inventory. There is some consignment inventory that is not on the balance sheet. The society has eight consignors. The society keeps 10 percent of all of the consignment sale proceeds. The Building \& Equipment line item includes all leasehold improvements in the museum and office space, since that is all rented space, and the office furniture, display tables in the store and museum, shelving in the archives, and office equipment such as computers and photocopy machines. The improvements, furniture, and equipment are all depreciated on a straight-line basis.

One thing that you might not have encountered before is that the archives and artifacts collections aren't in the Society's accounting records. The Society keeps a record of the items donated, but the items are only appraised if necessary for insurance purposes or for a donor's tax records, because appraisals are expensive. No one really even knows the total value of the items.

Jessie: Oh. That seems like a problem. Don't they have to report the assets on the balance sheet?

Al: I guess not. I'm not an accountant, so you would know more than me about that. They've never reported it in the past, so I assume that it is o.k.

Jessie: All right. I have another question about something you mentioned. You said the Society keeps its money in checking accounts, a savings account, and CDs. What about other types of investments? Is the Society earning much interest on these accounts?

Al: They don't earn any interest on the checking accounts, but they do earn about 2 percent annual interest on the savings account. They were earning about 6 percent on the CDs, but that is down to about 4 percent now. There aren't any other investments. In fact, one of the biggest donors for the endowment fund is pretty adamant that they not invest in anything risky. He likes CD's because they're safe. He doesn't want the Society to lose any of his money.

Jessie: Ok. I guess that makes sense. What other ways does the Society get money?

Al: Well, let's see. They get membership fees and donations on a regular basis, grants sometimes; they get funds from the county, gift shop sales, archive research fees, entrance fees for the museum and house. They also charge sometimes for special events, like special holiday programs. They don't take credit cards, so you don't have to worry about that. Erika records the receipts and makes sure all the cash and checks get put into the cash register. Robert makes the bank deposits. You just need to use the information from his deposits to record the revenues. 
Robert takes care of writing the checks for the expenses too. But you'll need to sign them. He holds on to them until you can stop by to sign them, but you should try to do that once a week. He'll give you the invoices, too, so you'll know how to record the expenses. I guess we should talk about the expenses too. Basically, the Society pays the employees twice per month on the second and fourth Tuesday, and then there are payroll taxes too. The rent for the building gets paid once per month. The rent includes the utilities and janitorial services for the building. There are also telephone bills every month, and charges for the Internet service. They also have accounting and legal fees, mainly for the annual financial statement audit; fees for the security alarms; repairs and maintenance on equipment; office supplies; bank charges; postage; newsletter expenses; insurance; advertising; dues and subscriptions; education or travel cost reimbursements for the staff; and inventory purchases for the gift shop. Any large, non-routine purchases, like for new furniture, have to be approved by the Finance Committee and the Board of Trustees.

Jessie: How do you account for all of the donated labor?

Al: We don't. We don't record income for the donation or expense for any cost, since we are not actually paying anything.

Jessie: What about liabilities? Does the society have a lot of debt?

Al: The only liability account currently is accounts payable, for unpaid invoices. There aren't any loans or other long-term debts. However, the auditors always accrue payroll at year-end. For 20x2, that would be $\$ 1,450$, in addition to $\$ 112$ in payroll taxes.

Jessie: Great! Thanks a lot, Al. This has been really helpful. I'm kind of nervous about my first board meeting. I've never done anything like this before.

Al: Oh, don't worry. They're all really nice people. Here, let me give you the most recent fund and activity reports. You'll need these to prepare your financial statements for the meeting.

Jessie: Thanks. It looks like I've got some work to do.

\section{GETTING READY FOR THE BOARD MEETING}

After meeting with $\mathrm{Al}$ Gone, Jessie takes all of her notes home, along with the reports $\mathrm{Al}$ gave her, to try to prepare for the board meeting. She wants to look like she knows what she's doing. After all, her boss has friends on the board, and she doesn't want them to tell him she wasn't prepared. But, she still has questions. She has to figure out how to prepare financial statements in the proper format. She also isn't sure about the accounting for the donated artifacts and archive materials. It just doesn't seem right not to report all of the assets on the balance sheet. And what about all the donated time from volunteers? Doesn't that have to be reported somehow? Besides the financial reporting issues, Jessie has questions about the company's cash management policies. Keeping all of the money in CDs seems too conservative and is earning the Society a really low interest rate. And the Society doesn't take credit cards-maybe they would get more attendance and make more sales in the gift shop if they allowed people to use charge cards. Jessie turns on her computer and gets busy trying to find the answers to her questions.

\begin{tabular}{|l|c|}
\hline \multicolumn{2}{|c|}{ Exhibit One: Marketing Fund Activity : 20x2 } \\
\hline Fund Balance-beginning & $\$ 6,250$ \\
\hline Donations & $\$ 5,000$ \\
\hline Advertising Expenses & $(\$ 2,340)$ \\
\hline Fund Balance-ending & $\$ 8,910$ \\
\hline
\end{tabular}




\begin{tabular}{|l|c|}
\hline \multicolumn{2}{|c|}{ Exhibit Two: Restoration Fund Activity 20x2 } \\
\hline Fund Balance-beginning & $\$ 38,720$ \\
\hline Donations & $\$ 15,349$ \\
\hline Interest Earned & $\$ 221$ \\
\hline Expenditures & $(\$ 12,950)$ \\
\hline Fund Balance-ending & $\$ 41,340$ \\
\hline
\end{tabular}

\begin{tabular}{|l|c|}
\hline \multicolumn{2}{|c|}{ Exhibit Three: Fixed Asset Fund Activity 20x2 } \\
\hline Fund Balance-beginning: & $\$ 392,914$ \\
\hline Building and Equipment & $(\$ 143,972)$ \\
\hline Accumulated Depreciation & $\$ 248,942$ \\
\hline Net & - \\
\hline Purchases of buildings and equipment & $(\$ 16,590)$ \\
\hline Depreciation taken & $\$ 232,352$ \\
\hline Fund Balance-ending & \\
\hline
\end{tabular}

\begin{tabular}{|l|c|}
\hline \multicolumn{2}{|c|}{ Exhibit Four: Endowment Fund Activity: 20x2 } \\
\hline Fund Balance-beginning & $\$ 191,770$ \\
\hline Donations & $\$ 2,500$ \\
\hline Interest & $\$ 3,656$ \\
\hline Fund Balance-ending & $\$ 197,926$ \\
\hline
\end{tabular}

\begin{tabular}{|l|c|c|}
\hline \multicolumn{3}{|c|}{ Exhibit Five: Operating Fund Account Balances At December 31 } \\
\hline Account & $20 \times 1$ & $20 \times 2$ \\
\hline Cash & $\$ 12,597$ & $\$ 14,491$ \\
\hline Accounts Receivable & 245 & 127 \\
\hline Prepaid Insurance & 342 & 365 \\
\hline Inventory & 2,423 & 2,824 \\
\hline Accounts Payable & 3205 & 2,962 \\
\hline Accrued Payroll and Related Taxes & 1484 & 1562 \\
\hline
\end{tabular}




\begin{tabular}{|l|c|}
\hline \multicolumn{2}{|c|}{ Exhibit Six: Operating Fund Activities 20x2 } \\
\hline Account & Amount \\
\hline County Support Funds & $\$ 78,323$ \\
\hline Donations & $\$ 16,853$ \\
\hline Membership Fees & $\$ 6,487$ \\
\hline Museum Admissions & $\$ 3,905$ \\
\hline Archives and Research Fees & $\$ 3,610$ \\
\hline Gift Shop Sales & $\$ 5,523$ \\
\hline Cost of Gift Shop Sales & $\$ 4,120$ \\
\hline Special Program Income & $\$ 5,116$ \\
\hline Special Program Expenses & $\$ 3,560$ \\
\hline Interest Income & $\$ 178$ \\
\hline Grant Income & $\$$ \\
\hline Wage Expense & $\$ 47,500$ \\
\hline Payroll Tax Expense & $\$ 3,845$ \\
\hline Accounting and Legal Fees Expense & $\$ 2,200$ \\
\hline Rent Expense & $\$ 40,463$ \\
\hline Telephone and Internet Expense & $\$ 952$ \\
\hline Alarm Expense & $\$ 1,385$ \\
\hline Repairs and Maintenance Expense & $\$ 2,074$ \\
\hline Office and Archive Supplies & $\$ 4,849$ \\
\hline Postage Expense & $\$ 903$ \\
\hline Newsletter Expenses & $\$ 255$ \\
\hline Advertising Expenses & $\$ 2,340$ \\
\hline Education and Travel Expenses & $\$ 220$ \\
\hline Grant Expenses & $\$ 50$ \\
\hline Insurance Expense & $\$ 5,304$ \\
\hline Depreciation Expense & $\$ 12,950$ \\
\hline Restoration Expenses & \\
\hline & \\
\hline
\end{tabular}

\section{QUESTIONS}

1. Is it appropriate for the Society to use fund accounting for internal purposes? Is the use of fund accounting acceptable for external reporting? What professional standards can be referenced to determine the appropriate accounting for external purposes?

2. Al told Jesse that some funds were restricted in nature. What is the difference between unrestricted funds and restricted ones? What is the distinction between temporarily and permanently restricted funds? How would you classify each of the five funds used by the society? Reference the appropriate professional standards to answer this question.

3. Is the Society accounting for its donated artifacts correctly? Reference the appropriate professional standards to address this question.

4. Aside from the accounting rules, what are the possible advantages and disadvantages of excluding all of the donated artifacts from the Society's balance sheet?

5. The Society, like most nonprofit organizations, could not continue to operate without the assistance of its volunteers. In the past, the Society has not recognized any contribution revenue for these services. Is this appropriate? Could you make an argument that Jessie Star's services should be recognized? Cite the appropriate professional standards.

6. Use the data provided in Exhibits 1 through 6 to create a statement of activities for 20x2 and balance sheets for 20x1 and 20x2, in accordance with SFAS 117. Remember to adjust for the payroll accruals at year-end, and assume that all other transactions were recorded correctly. 


\begin{abstract}
7. What are the issues that Jessie should consider in recommending an investment strategy for the Society? Do you think that the Society's current policy is appropriate? If so, why? If not, what would you recommend?

8. The Society currently accepts checks, but not credit cards. Why do you think that credit cards are not accepted? Discuss the pros and cons of accepting credit cards in an operation like the Society's.

9. Jesse's firm encouraged her to volunteer for this position. Why would firms view this type of service as important?
\end{abstract}

\title{
INSTRUCTOR'S NOTES
}

\section{Case Description}

This case involves financial reporting issues for nonprofit organizations and, in particular, how specialized entities, such as museums, can present unique financial reporting issues. Secondary issues examined include financial management issues at a nonprofit organization, the importance of volunteer work and the emphasis that employers often place on community involvement. The case is appropriate for a junior level course or higher. The case is designed to be taught in one to two class hours and is expected to require approximately three to four hours of outside preparation by students.

\section{Case Synopsis}

In this case, the students are introduced to Jessie Star, a recent accounting graduate who has just volunteered (at the urging of her boss) to be the treasurer for the local Historical Society. Jessie finds herself struggling to master the financial issues at the Society so that she will be prepared for her first board meeting. The Society uses fund accounting, which is something with which she is not very familiar. She is also struggling to understand why the Society has never reported its historic artifacts on its balance sheet as assets, even though they are quite valuable, and wonders if this could possibly be an approved accounting method. She is also astonished that all of the Society's investments are held in Certificates of Deposit earning fairly low interest rates, and wonders if there is a better investment strategy for the organization. The students must assume the role of Jessie and research these issues to formulate recommendations for the Society.

\section{Recommendations for Teaching Approaches}

This case can be assigned as an in-class discussion case or as an out-of-class research assignment. The case can be used as an introduction into not-for-profit accounting, as a review of not-for-profit accounting, and/or as a basis for discussion of financing concerns for non-profit organizations. This case also provides a good opportunity for instructors to open a discussion about the importance of volunteerism on the part of professionals and the ways in which finance and accounting professionals can contribute their expertise.

\section{ANSWERS TO CASE QUESTIONS}

1. SFAS 116 and 117 address this issue. For external reporting purposes, not-for-profit organizations are required to summarize activity and balances according to whether they are unrestricted, permanently restricted, or temporarily restricted, rather than reporting separate funds. The focus is on the organization as a whole, not on separate funds. However, for its own internal uses, the Society may choose to maintain separate funds to track restrictions on the type of expenditures allowed by donors. The society has funds donated for "temporarily restricted" purposes for a variety of different uses and must track those individual allowed uses separately. The society must know how much is available to spend on programs, on house restoration, on advertising, and so forth.

2. SFAS 117 (paragraphs 13 - 16, with specific definitions in the Glossary, paragraph 168) classifies net assets (the balances in the Society's various funds) based on whether the donor(s) imposed restrictions on how the funds are spent. Unrestricted net assets generally have no specific limitations on their use. Permanently restricted net assets may never be expended for purposes other than those set by the donor. If the donor- 
imposed restrictions expire at some point, or require that the assets be spent for a specific purpose or to acquire fixed assets, the net assets are classified as temporarily restricted. The Society's operating and fixed asset funds are unrestricted, the marketing and restoration funds are temporarily restricted, and the endowment fund is permanently restricted.

3. According to SFAS 116 (paragraph 11), contributions are normally reported when received, and are recorded as a credit to revenues and a debit to assets, liabilities, or expenses as appropriate. When historical items are donated for the purposes of adding to the society's collections, however, recognition is not required. Museums have a choice to:

A. record the donation at fair value as an asset and record a corresponding credit to revenue, or

B. not recognize the transaction in the accounting records. This choice can only be made if three conditions exist:

a. the item is to be held only for the purpose of research, public display, and education and not used for financial gain

b. $\quad$ the item is preserved and not used as collateral

c. there is a policy or an agreement that if the item is ever "de-accessioned" and sold, the money received is used only for the purchase of other artifacts.

The Society's archive and artifact donations meet the three criteria and, therefore, it is allowable to omit the items from the accounting records.

4. One definite advantage of excluding the artifacts from the balance sheet is avoiding the cost of appraisals that would be necessary in order to arrive at a dollar amount to record. Since the artifacts are donated and may be valuable only as a historical display or research record, obtaining a value is difficult. Also, showing a large amount of assets on the balance sheet may make prospective donors feel that the Society does not need their donations. That is, it may make the Society appear wealthier than it is. While the Society may have a large number of assets, it tends to have limited spendable funds.

On the other hand, omitting the items from the balance sheet can have negative consequences. The large number of archives and artifacts requires a great deal of management time and resources to catalogue and preserve the items. Being able to show a high dollar value for the items might help persuade funding agencies and other donors of the need for funds. Including the items on the balance sheet more accurately reflects the size of the organization.

5. SFAS 116 (paragraph 9) indicates that a contribution of a service should be recognized as revenue at its fair value (i.e. what the organization would have been billed) if it meets one of the following two criteria:

a. the service created or enhanced a non-financial asset of the organization

b. the service required a special skill, was performed with someone possessing that skill, and would otherwise normally have been purchased if a donation had not been obtained.

Services not meeting the criteria are not recorded as donations. Therefore, the majority of time donated to the Society would not be reported. Jesse Star's services, on the other hand, are specialized and would need to be recognized in future years. (Note that the previous treasurer was not an accountant; his services were not recognized).

Additional discussion could center on donated restoration labor for the historical home. The labor would increase the value of a non-cash asset and requires a special skill, so it meets the requirements for recognition. However, the Society does not own the house, but rather has a long-term agreement to operate it. Therefore, the improvements the Society makes to the house might be considered leasehold improvements and be capitalized on its books, with contribution revenue recognized for the services. 
6. The financial statements should be constructed as follows:

\begin{tabular}{|l|r|r|}
\hline County Historical Society Statements of Financial Position December 31,20x2 and 20x1 & $20 \times 1$ \\
\hline Current Assets: & $20 \times 2$ & \\
\hline Cash and Cash Equivalents & & $\$ 249,337$ \\
\hline Accounts Receivable & $\$ 262,667$ & 245 \\
\hline Prepaid Insurance & 127 & 2,423 \\
\hline Inventory & 365 & $\$ 252,347$ \\
\hline Total Current Assets & 2,824 & 392,914 \\
\hline Noncurrent Assets: & $\$ 265,983$ & $(143,972)$ \\
\hline Building and Equipment & & $\$ 248,942$ \\
\hline Less: Accumulated Depreciation & 392,914 & $\$ 501,289$ \\
\hline Total Noncurrent Assets & $160,562)$ & \\
\hline Total Assets & $\$ 232,352$ & 3,205 \\
\hline Current Liabilities: & $\$ 498,335$ & 1,484 \\
\hline Accounts Payable & & $\$ 4,689$ \\
\hline Accrued Payroll and Related Taxes & 2,962 & - \\
\hline Total Current Liabilities & 1,562 & $\$ 4,689$ \\
\hline Noncurrent Liabilities & $\$ 4,524$ & \\
\hline Total Liabilities & & - \\
\hline Net Assets: & $\$ 4,524$ & 259,860 \\
\hline Unrestricted & & 44,970 \\
\hline Temporarily Restricted & 245,635 & 191,770 \\
\hline Permanently Restricted & 50,250 & $\$ 496,600$ \\
\hline Total Net Assets & 197,926 & $\$ 501,289$ \\
\hline Total Liabilities and Net Assets & $\$ 493,811$ & \\
\hline
\end{tabular}



$\underline{3}$

\begin{tabular}{|c|c|c|c|c|}
\hline \multicolumn{5}{|c|}{ County Historical Society: Statement of Activities: For the Year Ended December 31, 20x2 } \\
\hline & Unrestricted & $\begin{array}{l}\text { Temporarily } \\
\text { Restricted }\end{array}$ & $\begin{array}{l}\text { Permanently } \\
\text { Restricted }\end{array}$ & Total \\
\hline \multicolumn{5}{|l|}{ Revenues and Other Support: } \\
\hline Donations & $\$ 6,853$ & $\$ 20,349$ & $\$ 2,500$ & $\$ 39,702$ \\
\hline County Support Funds & 78,323 & & & 78,323 \\
\hline Membership Fees & 6,487 & & & 6,487 \\
\hline Museum Admissions & 3,905 & & & 3,905 \\
\hline Archives and Research Fees & 3,610 & & & 3,610 \\
\hline Gift Shop Sales & 5,523 & & & 5,523 \\
\hline Special Program Income & 5,116 & & & 5,116 \\
\hline Interest Income & 178 & 221 & 3,656 & 4,055 \\
\hline Grant Income & 0 & & & 0 \\
\hline $\begin{array}{l}\text { Net Assets Released from Restrictions } \\
\text { (Program Expenditures) }\end{array}$ & $\$ 15,290$ & $\$(15,290)$ & & 0 \\
\hline Total Revenues and Other Support & $\$ 135,285$ & $\$ 5,280$ & $\$ 6,156$ & $\$ 146,721$ \\
\hline \multicolumn{5}{|l|}{ Expenses: } \\
\hline Cost of Gift Shop Sales & $\$ 4,120$ & & & $\$ 4,120$ \\
\hline Special Program Expenses & 3,560 & & & 3,560 \\
\hline Wage Expense & 47,500 & & & 47,500 \\
\hline Payroll Tax Expense & 3,845 & & & 3,845 \\
\hline Accounting and Legal Fees & 2,200 & & & 2,200 \\
\hline Rent Expense & 40,463 & & & 40,463 \\
\hline Telephone and Internet Expense & 952 & & & 952 \\
\hline Alarm Expense & 1,385 & & & 1,385 \\
\hline Repairs and Maintenance Expense & 2,074 & & & 2,074 \\
\hline Office and Archive Supplies & 4,849 & & & 4,849 \\
\hline Postage Expense & 903 & & & 903 \\
\hline Newsletter Expenses & 255 & & & 255 \\
\hline Advertising Expenses & 2,340 & & & 2,340 \\
\hline Education and Travel Expenses & 220 & & & 220 \\
\hline Grant Expenses & 0 & & & 0 \\
\hline Insurance Expense & 5,304 & & & 5,304 \\
\hline Depreciation Expense & 16,590 & & & 16,590 \\
\hline Restoration Expenses & 12,950 & & & 12,950 \\
\hline Total Expenses & $\$ 149,510$ & $\$ 0$ & $\$ 0$ & $\$ 133,035$ \\
\hline Change in Net Assets & $\$(14,225)$ & $\$ 5,280$ & $\$ 6,156$ & $\$(2,789)$ \\
\hline Net Assets-12/31/20x1 & 259,860 & 44,970 & 191,770 & $\$ 496,600$ \\
\hline Net Assets-12/31/20x2 & $\$ 245,635$ & $\$ 50,250$ & $\$ 197,926$ & $\$ 493,811$ \\
\hline
\end{tabular}

7. Jessie needs to consider the trade-off between risk and return, and the desires of the organization's contributors. Clearly, the Society is earning a low return on a substantial amount of funds. However, to invest in stocks and bonds creates more risk to the organization. Students can argue both sides of this issue.

The Society on which this case is based decided to revise its policy to adopt a balanced investment approach. More than half of its funds are still invested in conservative, low-yield CDs and other investments, but a portion of the funds is now invested in the stock market. A local bank's investment group is handling the funds. The Society plans to review the performance regularly and decide if a revision in its policy is necessary. The conservative approach was taken originally primarily because the donor of the Society's 
endowment fund insisted that the money be held in nothing riskier than CDs. Although some members of the board thought it was irresponsible to accept such low returns, the donor of the funds must be considered both to honor the agreements made when the funds were donated, and to encourage future donations from that individual.

8. The primary reason for not accepting credit cards is the fee charged to organizations for using the cards. Many students do not realize that a percentage fee is charged and that small organizations often are charged a higher percentage than large retail chains are charged. The potential benefits to accepting credit cards are a reduction in bad debts and a possible increase in sales or contributions if cards were accepted. The Society would need to compare any costs it has incurred for bad checks or nonpayment on research fees, along with an estimate of any potential sales increases, with the fees charged for card usage.

9. Students might discuss, among other things:
A. Corporate and individual social responsibility,
B. Visibility for the firm, and
C. Making contacts with other individuals and firms (networking). 